(C) D.V. Mikhel

\title{
INTELLECTUAL COMMUNITY DISCUSSES THE COVID-19 PANDEMIC: THE CORONAVIRUS DEBATE AS A NEW CULTURAL PHENOMENON
}

Keywords: COVID-19 pandemic, intellectuals, discussions, Europe, Russia, Giorgio Agamben, Slavoj Žižek, Sergey Kurginyan

\begin{abstract}
This article examines the phenomenon of the recent debate about the COVID-19 pandemic, in which leading intellectuals of our time have become involved. The special position taken by intellectuals today is reflected in the sharpness of their statements on the pandemic and their attempts to distance themselves from the official position on coronavirus infection taken by most doctors, virologists, and politicians. Using the channels of information available to them - journals, TV channels, Internet sites - intellectuals tend to view the pandemic as a global crisis capable of radically changing the lives of entire societies and humanity. The Italian philosopher Giorgio Agamben speaks of COVID-19 as an emergency invented by the authorities, depriving humans of all the attributes of existence except "naked life". The Slovenian thinker Slavoj Žižek proclaims the thesis that the answer to the coronavirus can only be a renewed communism. The Russian political scientist Sergey Kurginyan interprets COVID-19 as a global systemic disaster with political, economic, anthropological, and other aspects.
\end{abstract}

This article is a translation of: Д.В. Михель. Интеллектуалы обсуждают пандемию COVID-19: дискуссии о коронавирусе как новое культурное явление // Etnograficheskoe Obozrenie. 2021. No 6. P. 62-80. DOI: 10.31857/S086954150017928-0

The current COVID-19 pandemic represents not only a real threat of infection, illness, and loss of life for the vast majority of people on the planet but also an endless related information buzz. It is becoming more and more difficult to hide from the deadly virus, but it is even more difficult to shy away from the flood of news and different rumours accompanying its spread. This makes the spread of COVID-19, among other things, a discursive event. All groups of society are involved in the conversation about the pandemic, but the most significant participants in the discussion are virologists, doctors, politicians, and intellectuals. Everyone is concerned about what the former two categories say, since they are viewed by the public as the primary experts on the above issues. Politicians' opinions attract attention only because the decisions they make and concrete administrative measures they enforce depend on what they say. The positions of intellectuals often run counter to the views of other opinion leaders. Intellectuals are bearers of critical thinking in the contemporary world - they follow the Cartesian principle: "If I doubt, I exist". It is these people who claim to be the true conscience of the nation, the advanced and independent voice of the minority.

Dmitry Mikhel | https://orcid.org/0000-0003-2250-1626 | dmitrymikhel@mail.ru|Russian Presidential Academy of National Economy and Public Administration (82 Vernadsky Prospekt, Moscow, 119571, Russia)

Etnograficheskoe Obozrenie. 2021. № 6. P. 314-330 https://doi.org/10.31857/S086954150017612-3

(C) Russian Academy of Science | (C) Institute of Ethnology and Anthropology, RAS

ISSN 0869-5415 | http://journal.iea.ras.ru 
Before the advent of the Enlightenment and the spread of universal literacy, any educated person could be considered an intellectual; subsequently, this notion began to refer mostly to people connected with literature and journalism. The hallmarks of the intellectual in the twentieth century were one's scientific work and teaching at the university. According to Foucault, whereas intellectuals were deemed to be multi-hyphenates in the past, originating from the sphere of law, nowadays they can be represented by specialists in various narrow domains, including natural science. Nevertheless, they are still distinguished by their particular political position: their willingness to disassociate themselves from the ruling authorities and to speak on behalf of the rest of the society (Foucault 2002: 205-206).

The scientific observation of intellectuals' activity during the pandemic reveals the following: everything they do boils down to the words they speak and the texts they produce. These are people who write and talk about the pandemic - being writing machines and talking heads. It is almost impossible to find anything else beyond this in any spheres involving intellectuals. Their texts are devoid of colloquialisms and are constructed according to the norms of literary speech. Where they speak - precisely in their status of intellectuals - they reproduce their own texts, in the first place. For this reason, the way they speak recedes to the background, while what they say comes to the forefront. Owing to intellectuals, the broad variety of opinions on the pandemic provokes a lively debate. The coronavirus debate that emerged in early 2020 has already become a cultural phenomenon. The quality and urgency of this debate are determined by the prominence of involved intellectuals, the semantic richness of texts pronounced/written by them, and the critical political stance they have taken. This article focuses on the positions regarding the current pandemic, taken by the three most prominent intellectuals of the time, who succeeded to impart particular significance and poignancy to the general conversation on COVID- 19.

\section{"Our society no longer believes in anything but the stripped-down life" (Agamben)}

Giorgio Agamben, the Italian philosopher and essayist, was one of the first in Europe to initiate a discussion on the coronavirus pandemic. This was facilitated by the fact that he had already had a track record of conceptualisation of the problems connected with power mobilisation, state of emergency, and biopolitics (Agamben 2011). In addition, he had contacts with the Quodlibet publishing house in Macerata where he launched his own column on the website in May 2017. Moreover, Italy was the first European country to face the pandemic in 2020. Agamben started this discussion as a public intellectual with a penchant for denial of violence and nonacceptance of attacks on civil liberties. The essays he published in Quodlibet evoked broad discussion in various countries. In Russia, they were also actively commented upon (Bossong 2020; Wagner 2020; Zhaivoronok 2020; Kaspe 2020a, 2020b; Kozenko 2020; Rudnev 2020).

On February 26, 2020, Agamben published an essay "Inventing the pandemic" (Agamben 2020a) in which he appeared as a sceptic rejecting the reality of the pandemic and believing that the authorities were using the coronavirus as a pretext to impose tighter controls on the society. Weighing each phrase accurately, Agamben expressed his opinion of what was happening, as follows:

It has been estimated that only $4 \%$ of patients need hospitalisation in intensive care... If this is the real situation, then why do the media and the authorities work hard to spread the atmosphere of panic, causing the present-day state of affairs with severe restrictions on relocation and suspension of normal living and working conditions in all regions? Two factors may help to explain this disproportionate behaviour. In the first place, one can observe again a growing tendency to use the state of emergency as a normal paradigm of the government... Another factor, no less disturbing, is the fear that has apparently spread in recent years in people's minds and which translates into a real need for collective panic for which the epidemic is an ideal pretext (Agamben 2020a). 
This critical position was formulated only five days after the first cases of coronavirus were reported in Lombardy and almost a month after the Italian government imposed a state of emergency on January 31, 2020, cutting off air communication with China where the first hotspot of infection had developed. The number of people infected in Italy during the first week of the SARS-CoV-2 virus spread was growing rapidly, but was not still threatening, which probably made Agamben conclude that the government was acting inappropriately. From his point of view, the Italian authorities, by imposing the state of emergency, did what Hitler did in Germany in 1933 and what the US authorities did in 2001, i.e. legitimised the factual lawlessness and reduced the full-fledged human life to the state of "stripped-down living", where nothing remains of a personality except the need to survive, while any legal identity of a person is discarded (Agamben 2011: 7-12). The emergency measures adopted by the end of January 2020 in Italy included the control of all arrivals from China - both of Chinese and Italian nationals who might have contacted with the former, - their segregation and medical surveillance (Interfax 2020; Country review 2020:2).

Agamben's statements provoked a reaction in the community of European intellectuals. As early as February 27, 2020, Jean-Luc Nancy, one of the most prominent figures in France, responded to Agamben on the Quodlibet website:

Fellow Giorgio Agamben claims that the coronavirus is almost indistinguishable from the normal flu. He forgets that there is a vaccine for "normal" flu that has been proven effective... Giorgio claims that governments use all sorts of pretexts to continually impose a state of emergency. But he fails to note the fact that the state of emergency is indeed becoming a rule in the world where technical interaction of all kinds (relocation, movement of any type, impregnation with or distribution of various substances, etc.) is reaching a hitherto unprecedented intensity that is growing at the same rate as the population... We should be cautious not to miss out - the entire civilisation is in question, there is no doubt about it... Almost thirty years ago the doctors decided that I needed a heart transplant. Giorgio was one of the few who advised me not to listen to them. If I had followed his advice I probably would have died pretty soon (Nancy 2020).

On March 9, 2020, the Italian authorities resorted to new anti-epidemic measures: the state of emergency was extended and the stay-at-home regime was introduced in Lombardy, Veneto, Emilia-Romagna, Piedmont, and Marche; public events and travel were banned, schools and public places were closed, religious rituals including weddings and funerals were suspended, restrictions on opening hours for bars and restaurants were introduced, a ban on unwarranted departure from home was introduced; serious fines and arrests were introduced for violation of the adopted measures. In addition, foreigners' entry to Italy was restricted (Country review 2020: 4-5). Agamben responded to these events almost immediately by publishing a new essay in which he continued to insist on the fact of fabrication of the pandemic and escalation of panic:

One of the most inhuman consequences of panic, which they are trying to spread in Italy as intensely as they can in connection with the so-called coronavirus epidemic, virtually rests on the very idea of contagion that underlies the state of emergency declared by the authorities... Another consequence of these decisions, the one even sadder than the restriction of freedoms... is the degradation of relationships between people generated by this situation. You are not allowed to approach or touch another person, whoever he/she may be, even your loved one, and there must be a distance of supposedly one metre at least between you both, which according to some recent proposals of the so-called experts should rather be 4.5 metres... So your kith and kin, your dear ones are now required to be apart from you. Possibly, given the ethical inconsistency of our authorities, these decisions are motivated by the intention to provoke the same fear. $<\ldots>$ Those who reign have already tried many times to achieve a situation when the universities and schools would be closed once and for all, lessons would be given only on the Internet, we would stop meeting and talking about politics or culture and would only exchange digital messages (Agamben 2020b). 
This statement provoked a strong reaction of the Italian media, so six days later Agamben had to talk about the panic again, about the disruption of usual social ties and other consequences of the state of emergency. The appearance of his next essay coincided with the Italian government's decision of March 17, 2020 to allocate $€ 85$ million to promote online education and to support the parents during school closures (Country review 2020:14). The transition of Italian schoolchildren and students to the distance learning format was an occasion for Agamben to state the following:

The first thing that becomes obvious due to the wave of panic that has paralysed the country is that our society no longer believes in anything but stripped life. $<\ldots>$ Italians are ready to sacrifice almost everything - the normal way of life, social relations, job, even friendship, affection, religious and political beliefs - in order not to fall ill. The stripped life and fear of losing it does not unite people, but blinds and divides them... The other thing... is that the state of emergency we have been made to reconcile with by the governments has indeed become a normal condition for long... The emergency measures actually oblige us to live under curfew. But the war with the invisible enemy who may lurk in any other person is the most absurd of wars... We are concerned not so much about the present, or in general not only about it, but are anxious what comes next. Just like a series of unfavourable technologies the world was left with after the wars - from barbed wire to nuclear power plants, - it is much likely that after the health experiments that proved not to be successful the authorities will make sure that the universities and schools close... that machines replace any contact and any contamination - between humans wherever possible (Agamben 2020c).

In another ten days, Agamben, wondering why the Italian society had so readily accepted the imposition of the state of emergency, gave his version of it:

The hypothesis I would like to propose is that in some way, maybe unconsciously, the plague had come to us long ago, and obviously the conditions of people's lives had been prepared for it for a long time already, so the sudden call was sufficient for them to get exposed as they were - unbearable, like during a plague... Never before have we witnessed the spectacle typical of religions at times of crises... And one more thing gives further food for reflection: the apparent collapse of universally shared beliefs and opinions. It seems, people no longer believe in anything except the stripped biological existence that must be preserved at all costs. But it is only tyranny, only a monstrous Leviathan with a drawn sword (Agamben 2020d), that can be based on the fear of losing life.

Raising this issue, Agamben seems to have had an opportunity to see that his own political position as an intellectual did not coincide with the choice of the vast majority of the Italian society.

On April 10, 2020, the Italian government took a decision to extend all previously introduced pandemic control measures until May 3, 2020. By that moment, the country had already become the world leader in the number of people infected and dying from COVID-19. The Italian Ministry of Emergency took a decision to set up an emergency medical response team to help the worst affected regions. The country started receiving humanitarian aid from China, Russia, and other countries (Country review 2020: 6, 9, 1617). It was no longer possible to talk about the fabrication of the pandemic, so Agamben switched to discussing the changes in social life caused by the emergency measures - the issue that concerned a huge number of people both in Italy and abroad. The reason for the intellectual's next statement was the new term "social distancing" that emerged somewhere around that period:

Although the term has probably been taken as a euphemism for the hitherto used unpleasant term "isolation", it is expedient to find out the specifics of the political order to be based on it... Although there are fools, as ever, who trust that the situation that has arisen can undoubtedly be considered positive and that the new digital technologies have ensured pleasing communication at a distance for a long time already, I do not believe that a society 
based on "social distancing" is humane and politically viable... It will remain as we see it today - a sparse body of people basing their existence on prohibition, but being particularly clenched and patient precisely for this reason (Agamben 2020e).

Continuing to reflect on the changes in the social life caused by a regular decision of the authorities to extend the state of emergency, Agamben, in his text as of 13 April, tries to analyse the causes of moral and political degradation of the Italian society, when even the priests and lawyers waive their duty to care for afflicted people:

I would like to discuss with you a question that I have not stopped thinking about for over a month now. How could it happen that the entire country collapsed morally and politically in the face of the disease and not even realised it? The words I have used to formulate this question have all been carefully considered... The principle proclaiming that one must deny the good in order to save the good is as false and contradictory as the principle stating that one must deny freedom in order to protect freedom (Agamben 2020f).

On April 14, after a lengthy lockdown and in connection with the degression of the pandemic, Italian authorities began to lift the imposed restrictions. Some shops were opened, including those selling goods for children. In response to the decisions, Agamben posted two expatiative descants on the website Quodlibet on April 20 and 24 about how the society had changed in the passed months. He noted the following, in the first place: "As one would have expected, while we were trying to remind the same to those who preferred to close their eyes and ears, the so-called phase two, or return to the norm, would be even worse than anything we have experienced so far". He drew special attention to the fact that people over 70 were forbidden to return to normal social life. The philosopher, who belongs exactly to this category by age, called this decision "unconstitutional discrimination" creating "a class B group of citizens" who would remain deprived of freedom and would be subjected to risks harmful to health (Agamben 2020g). Agamben also noted that although the mortality caused by the coronavirus was lower than the statistics of deaths from other diseases, it was the COVID-19 pandemic that triggered the introduction of the state of emergency and the nascence of "the new despotism":

In Italy... we have long been accustomed to emergency decrees by the executive power which substitutes the legislative power this way and factually abolished the principle of separation of powers on which democracy is based. Meanwhile the surveillance by video cameras, and now, as supposed, by mobile phones, is far superior to any form of control carried out under totalitarian regimes such as fascism or Nazism (Agamben 2020h).

The weakening of the pandemic in Italy and the gradual release of restrictive measures at the turn of April and May 2020 encouraged Agamben to review his intellectual experience. His new successive essays were no longer a response to the authorities' anti-epidemic measures, but rather an attempt to understand what had happened, why it had been possible, and what consequences it had caused. In the essay with a remarkable title "About truth and lies", the intellectual resorted to extensive use of his own concept of the state of emergency. In particular, he noted that the authorities had not only restricted citizens' constitutional rights to freedom of relocation and other forms of activism, but also the rights "that are not enshrined in any constitution: the right to truth, the need for a truthful word" ( $\mathrm{Ag}$ amben 2020i). According to Agamben, the measures taken to counter the pandemic should have been a subject of conceptualisation, but instead, a total ban on analysis and the free exchange of opinions was imposed:

What we are experiencing is in fact a Titanesque operation to falsify the truth, to be followed by unprecedented manipulation of everyone's freedoms. If people agree to limit their 
personal freedom, this is because they accept the data and opinions provided by the mass media, without any verification (Ibid.).

In addition to the fact that advertising has dishabituated people to think critically, now, at the time of the pandemic and the barrage of related information, it is not even the vacancy of mind that has been absolutised, but the lie. "Humanity is entering the phase in its history where truth is reduced to a passing moment in the movement of the false. The truth lies in the fact that false statements must be true even when their falsity is proven. But in this way, language itself, as a tool of expressing truth, is confiscated from man" (Ibid.). Summarising his discourse, Agamben urged his readers to resist falsehood and engage in the search for a "true word" which is the highest value in the current historical circumstances.

Starting from May 2020, when the epidemic situation in Italy stabilised, Agamben concentrated on general philosophical issues related to the policy of limiting freedoms during the pandemic. The philosopher speaks not so much about the danger of the virus, but about the administrative and political measures to combat it, and concludes that the society must remain extremely cautious about the direction in which the power evolves in the conditions of the state of emergency, and should prevent descending into totalitarianism even in pursuit of high goals. In his subsequent essays (see e.g.: Agamben 2020j, 2020k and others), Agamben takes the position of implacable defender of civil liberties in his column on the Quodlibet website, continuing to prophesy new real and potential dangers to the society in connection with the persistent attempts of the authorities to take control of the social life in the name of defeating the virus.

\section{"The coronavirus... will force us to reinvent communism" (Žižek)}

A Slovenian philosopher Slavoj Žižek, another bigname of modern European thought, joined the discussion on coronavirus infection even slightly before Agamben. Even before SARS-CoV-2 spread to Europe, the intellectual reacted to the news of its onset in Wuhan, China. In his first discourse about the new disease, he poses three questions: How to fight with the unknown virus? Is the multimillion city of Wuhan with its deserted streets a prototype of a city of the future? Why do Europeans remain racists, willing that all Chinese are quarantined? Žižek gave a remarkable answer to the first question: "One thing is sure: Isolation, and further quarantines, will not do the job. Full unconditional solidarity and a globally coordinated response is needed, a new form of what was once called communism" (Žižek 2020g). Žižek's statement made in early February was not yet truly appreciated in Europe, but just a month later it acquired its full-on meaning. Like Agamben, Žižek spoke about the importance of solidarity and cooperation, using, however, not the liberal thesis about civil freedom, but the leftist one - about communism. The difference between the positions of Žižek and his Italian colleague was in the willingness of the former to admit the existence of the coronavirus from the very beginning, as well as the fact of its deadly danger.

Responding to the news about the cruise ship Diamond Princess that was quarantined at the port of Yokohama with its 3,700 passengers (TASS 2020), Žižek published an essay on February 14, 2020 where he eloquently stated: "We are all in the same boat, and its name is the Diamond Princess". Reflecting on the situation with the liner passengers, the intellectual criticised the policy of Chinese leaders hiding the information about the true scale of the epidemic from its citizens. At the same time, he assumed that China's authoritarian regime was able to cope with the coronavirus challenge, while the same would be a problem for the liberal democratic world:

During the epidemic, the state must be strong because it is supposed to take large-scale measures and enforce military discipline (e.g. quarantine). China has been able to isolate tens of millions of people. Imagine for a moment such a mass-scale epidemic in the United States; would the state be able to apply the same measures? I would bet that thousands of armed 
libertarians would break through the road, suspecting that the quarantine is a government conspiracy (Žižek 2020h).

On February 20, when the threat of a coronavirus infection was already announced in Italy and other European countries, Žižek wondered in what way society would be able to accept the fact of the growing epidemic. Drawing on Elisabeth Kübler-Ross' widely known concept of five stages of reaction to the information about imminent death - denial, anger, bargaining, depression, acceptance - Žižek concluded that all the other traumatic events - environmental disaster, the threat of digital control over individuals' lives, Trump's presidency, reaction to plague in medieval cities - are perceived by society according to the same scheme:

What we should accept, what we should reconcile ourselves with, is that there is a sub-layer of life, the undead, stupidly repetitive, pre-sexual life of viruses, which always was here and which will always be with us as a dark shadow, posing a threat to our very survival... (Žižek 2020i).

Nevertheless, Žižek ventured to clarify, with his peculiar urge to offer at least basic solutions to posed questions, the consequences of recognition of the pandemic as a fact: acceptance would mean either re-normalisation of the disease or mobilisation of everybody in the fight against it.

On February 27, the day after Agamben published his essay on the contrived pandemic, Žižek spoke about the significance of ideological viruses, in particular, about global social solidarity that would allow liberation from living under the present conditions of a nation-state. Drawing on the example of the Chernobyl accident which, in his opinion, had contributed to the collapse of the USSR, Žižek suggested that the COVID-19 pandemic would contribute to the collapse of capitalism. "The coronavirus will... compel us to re-invent communism based on trust in the people and in science... We cannot go on the way we were up until now... Radical change is needed" (Žižek 2020j). The coronavirus, as Žižek stated, is a signal that the world may not be the same as before. Living in the pandemic world would require new-quality global health care and other forms of "effective global coordination". In addition, the philosopher spoke negatively about the resurgent capitalist animism traditionally resting on the market and capital and voiced the related concern that the markets were sagging under the COVID-19:

Does all this not clearly signal the urgent need for a reorganization of the global economy which will no longer be at the mercy of market mechanisms? We are not talking here about old-style communism, of course, just about some kind of global organization that can control and regulate the economy, as well as limit the sovereignty of nation-states when needed (Ibid.).

Previously this used to take place in the context of wars. Now that there is a "medical war" with the virus, this limitation has also become relevant (Ibid.).

In early March, when most European countries began to impose restrictive measures to deal with the pandemic, Žižek spoke emphatically and unequivocally: "As panic over coronavirus spreads, we have to make the ultimate choice - either we enact the most brutal logic of the survival of the fittest or some kind of reinvented communism with global coordination and collaboration" (Žižek 2020k). In doing so, the intellectual rejected the option of Chinese communism, identifying it with the European version of limiting freedoms, and supported the approach of the WHO Director-General who called for mobilisation in the face of the viral danger and appealed to follow the clear commitment:

I am not a utopian here, I don't appeal to an idealized solidarity between people - on the contrary, the present crisis demonstrates clearly how global solidarity and cooperation is in the interest of survival of all and each of us, how it is the only rational egotist thing to do... 
The broad communist approach I am advocating is the only way for us to really leave behind such a primitive vitalist standpoint (Žižek 2020k).

On March 14, in the interview with The Spectator, Žižek stated that a "perfect storm" was looming over Europe - the COVID-19 pandemic and a surge of uncontrolled migration, coinciding in time. This "storm", as the intellectual believes, will weaken Europe and can only be countered by turning to communism:

Of course, I don't mean the old-style communism. By communism, I mean simply what the World Health Organization is saying. We should mobilize, coordinate, and so on. ... They're saying this country lacks masks, respirators, and so on. We should treat this as a war. Some kind of European coordination...maybe even wartime mobilization (Žižek 20201).

Two days after the interview, on March 16, Žižek published an extensive essay that combined his earlier concepts about the coronavirus, the panic, and the importance of the "WHO-type" communism in counteracting the spread of SARS-CoV-2. Notably, in that text, Žižek also spoke out about Agamben whose position he identified as "leftist". The Slovenian philosopher gently rebuked his Italian colleague for underestimating the reality of the pandemic and overestimating the role of government measures to limit civil liberties:

Social interpretation doesn't make the reality of the threat disappear. Does this reality compel us to effectively curtail our freedoms? Quarantines and similar measures, of course, limit our freedom, and new Assanges are needed here to bring out their possible misuses. But the threat of viral infection also gave a tremendous boost to new forms of local and global solidarity, plus it made clear the need for control over power itself.... The challenge that Europe faces is to prove that what China did can be done in a more transparent and democratic way (Žižek 2020c).

According to Žižek, today’s liberal Europe has a lot to learn from authoritarian China in terms of pandemic control. The main threat, according to the philosopher, may be constituted in a situation when the measures applied by the authorities in both China and Italy may for some reason be aimed not at curbing the epidemic, but at manipulating the real data about it. On March 16, another text by Žižek appeared in Philosophie Magazine released in Paris, in which the philosopher stated: "In terms of the higher order of things, we are a species that can be disregarded" (Žižek 2020d). The philosopher turned again to the concept of staged response to information about death and stressed that mankind must accept the fact of the pandemic and abandon the thesis of own exceptionalism.

On March 18, Žižek spoke at Critical Inquiry about the consequences of the pandemic for humanity. What will the new world be like? Will it be a primitive barbarism where the strongest survive, or a "barbarism with a human face", where the society and the powers decide whether to help elderly sick people in the conditions of deficit of resources? In the polemic with Agamben, Žižek stated that the "stripped life" and the threat to lose it is not just the factor that separates people; it is also the situation that "unites them at the same time: maintaining social distance allows one to show respect for the others, since anyone can be a virus carrier". In the same text, Žižek reiterated the need for a broadest social coordination, or "military communism":

We are caught in a triple crisis: medical (the epidemic itself), economic (which will hit hard whatever the outcome of the epidemic), plus... the mental health - the basic coordinates of the life-world of millions and millions are disintegrating, and the change will affect everything, from flying during holidays to everyday bodily contacts. We have to learn to think outside the coordinates of stock market and profit and simply find another way to produce and allocate the necessary resources. Say, when the authorities learn that a company is keeping millions of masks, waiting for the right moment to sell them, there should be no negotiations with the company - masks should be simply requisitioned. (Žižek 2020e). 
On March 28, Žižek addressed the issue of how to survive during the pandemic. The answer he offered was: don't panic, don't rush off towards spiritual quests, continue with your usual routine. Žižek calls for learning to be content with what we have and prompts us to remember that many people do not have and will no longer have what they held dear before. "The main task is to structure your daily life in a stable and meaningful way". To keep working, to hold conferences, to take care of children. "It's the idea of a world where you have a flat, basics like food etc., the love of others and a task that really matters, now more than ever". If one manages to keep doing what one is accustomed to do, without any hope of getting paid for the work, without any hope for a future vacation, then such a life can be considered worthwhile. "I hope that some of this stance will survive when the pandemics will hopefully pass" (Žižek 2020m).

On April 2, Žižek spoke in The Philosophical Salon about the two ways of life caused by the pandemic: the first one is characteristic of a doctor, caregiver, or grocery deliverer - this is an exhausting work of patient care, tiring but meaningful work; the second one is total inactivity during the home-stay self-isolation (voluntary or involuntary) requiring search, rationale, and socially meaningful activity. "When a medical worker gets deadly tired from working overtime, when a caretaker is exhausted, they are tired in a way that is totally different from the exhaustion of being obsessed with career moves" (Žižek 2020f). In late April, in one of his texts, Žižek writes about the features of sexual life during the pandemic: "The Covid-19 epidemic will certainly give a boost to digital sexual games, but hopefully it will also lead to a new appreciation of physical intimacy and we will remember that sex between two people is a medium for spirituality" (Žižek 2020n).

Ten days later, Žižek devoted his next reflection on life under the pandemic conditions to the celebration of May Day. Who does this holiday belong to today? Certainly not the workers of industrial enterprises. Only nurses, caregivers, and servants continue to toil in the face of plant and factory closures. "This new working class was here all the time - the pandemic just propelled it into visibility". These people, Žižek notes, are doubly exploited: they have to work for sustenance, and in doing so they run the greatest risk of becoming infected by caring for others. "They are not just exploited in what they are doing - they are exploited in their very existence" (Žižek 2020o).

On May 5, Žižek published a new essay in which he compared the pandemic to an ongoing war. Without mentioning Agamben's name, he criticised a number of groups (rightwing libertarians in the USA and the left in Germany) that appealed for abolition of the quarantine treated by them as a means to "disciple people". The philosopher noted bitterly that so far no scientists knew "how the epidemics works". However, the virus will certainly change our (European) attitude towards both death and life, he stated. "What makes the epidemics so unbearable is that even if the full catastrophe fails to appear, things just drag on". Therefore, Žižek stressed, this is something we shall have to learn to live with. "The secret wish of all of us, what we think about all the time, is just one thing: when will it end? But it will not end". According to the intellectual, the popular-science media were too much caught up by digital technologies and overlooked the advent of the pandemic. When the coronavirus appeared, it became quite clear that for all the awesomeness of the digital world promised by the media, people still exist in a corporeal way. We all have to learn to live a new, more frugal life - sharing resources with the most disadvantaged people, establishing cooperation between countries, ending wars. Proclaiming this statement, being most Marxist in nature of all his previous discourse on the pandemic, the Slovenian intellectual once again summed up everything he had said before (Žižek 2020p).

In his subsequent texts about the coronavirus, Žižek repeatedly returned to his favourite theses: the need for greater solidarity in the face of the pandemic; the disastrous situation of the "new working class"; the bogus salvation through self-isolation practices; the need to learn to live in a new way in the face of the incessant viral danger. In fact, any coming news item - technocrats' initiatives for greater digitalisation, anti-racist campaigns in the United 
States, criticism of President Trump's political course by American democrats, etc. - became a pretext to repeat the philosopher's previously voiced statements.

Žižek's merit as an intellectual is his undoubted invariable ability to bring together a variety of disparate topics, placing them in the context of pandemic events. For instance, on May 14, when the first wave of the pandemics in Europe was receding, he astutely observed that people would need to learn not just to live in a new way, but to live differently from what the modern leaders of high-tech capitalism suggested to them, namely, to be protected, although silent, physically isolated, connected through the net of electronic communications. Quoting one of the slogans that emerged during the 2019 protests in Chile, Žižek seemed to be trying to express his own, truly innermost thought: "Another end of the world is possible.... Yes, our old world has come to an end, but a no-touch-future is not the only option, another end of the world is possible" (Žižek 2020q). Continuing to emphasise his political leftism, Žižek was insistently returning to the central thesis of his philosophy: the pandemic is deadly dangerous, therefore the government must act more radically and effectively, while it is the time for the European society to finally rise from the mire of consumption and start living in a more reasonable and responsible way (Žižek 2020a, 2020b).

\section{"The scale of the systemic disaster called coronavirus is too great" (Kurginyan)}

The discussions about the pandemic in Russia began a little later. In the spring of 2020, a number of media outlets made attempts to mobilise Russian intellectuals by addressing the leading sociologists, social anthropologists, and philosophers with questions about the coronavirus situation. This was followed by special issues about the pandemic in some academic journals; for instance, on July 10, the Public Opinion Foundation (FOM) launched a project CoronaFOM which began to publish Russian experts' opinions on various social, psychological, and other aspects of the pandemic on a regular basis. A great number of such expert judgments were soon summarised, and a book describing the project and its results was published in 2021 (Oslon 2021).

The debate about COVID-19 got undoubtedly escalated when a Russian political scientist Sergey Kurginyan joined it and raised the issue of the political situation in the country and in the world in connection with the pandemic. Kurginyan, one of Russia's most prominent intellectuals, criticised the current political system for years, viewing the current Russian state as a product of a project aimed to bring Russia into the Western world as a cultural colony, first launched under Boris Yeltsin and continued even after his withdrawal. However, according to Kurginyan, the ruling elite led by President Vladimir Putin, realising the country's impending disintegration, preferred to partially reconsider this course, although no full transition to an entirely sovereign state and related mobilisation of the whole society was ever achieved. Nevertheless, the search for a new model of Russian statehood was initiated, which resulted in the recent years' consensus between the authorities and the absolute majority of the country's population. However, according to the political scientist, this consensus soon came into question since the fight against the coronavirus revealed the inability of the ruling regime to establish a meaningful dialogue with the society, especially as concerns the pandemic and particularly the vaccination programme launched in the autumn of 2020. The compulsory vaccination of the population, according to Kurginyan, in the absence of utmost clarity about the nature of the coronavirus infection is fraught with the impending split of the society and, as a consequence, the disintegration of the country, which is so much desired by Russia's numerous enemies.

Kurginyan joined the COVID-19 discussion in late March 2020, immediately following the most prominent Western intellectuals. Initially, his podium was the Russian TV channel "Rossiya 1" ["Russia 1"]. On March 31, the political scientist got an opportunity to express his concept of the pandemic as a man-induced global crisis designed to abolish the existing model of globalisation (where China managed to surpass the United States) and to introduce 
a new model with new rules beneficial for the West. This coronavirus crisis, according to the intellectual, enables Russia to interfere in the big game of the world leaders and, in the course of the global turmoil, to recreate a strong nation-state with a healthy economy and well-developed social sphere (Kurginyan 2020a). On April 21, during another political talk show, Kurginyan stated that the COVID-19 pandemic should be considered systemically, and it does not matter whether the coronavirus was artificially created or emerged naturally. "All the processes - economic, psychological, military any other" - get unfolded against the backdrop of this factor (Kurginyan 2020b).

A few days later, Kurginyan publicly announced a series of video programmes about the coronavirus crisis on his Internet channel. On April 26, he presented an extensive lecture to a broad audience in which he wondered whether the Russian authorities would be able to survive the coronavirus crisis (Kurginyan 2020c). On May 3, as part of his multi-year Internet project "The Meaning of the Game", Kurginyan voiced a thesis: the Russian society needs to assess the unfolding situation more soberly and get mobilised (Kurginyan 2020d).

On May 12, the political scientist finally launched the promised series of programmes about the pandemic, presenting the first lecture that was based on the decision of the RF Prosecutor General's Office to restrict the dissemination of information about the artificial origin of the coronavirus. In the course of its presentation, Kurginyan consistently read out a number of texts, both by Russian and foreign authors, with due questions and comments. To cite just one example: "Stated differently, two years ago the US government had information - about what? About the natural virus or the artificial pathogen?" At the end of the lecture, Kurginyan quoted the opinion of French virologist Luc Montagnier laureate of the 2008 Nobel Prise for the discovery of HIV virus: "It the (coronavirus) is not of natural origin, then it is the work of molecular biologists... Possibly, they were willing to produce an anti-AIDS vaccine" (Kurginyan 2020e).

Three days later, in another discourse, Kurginyan spoke about the consequences of the pandemic. Like Agamben, he concluded that the spread of SARS-CoV-2 would lead to changes in education. Quoting the Russian experts, he pointed out that most of the young people would become consumers of low-quality online content, while good education will be a privilege of the few. According to Kurginyan, "the coronavirus does not exist by itself... outside of political agendas, military ventures, beyond economics". Kurginyan commented on a number of past years' documents, concluding on their basis (similar to Agamben) that the pandemic had been invented. However, unlike the Italian intellectual, the Russian political scientist associated that fact not with the authorities' desire to take control of their own societies, but with the desire of the global hegemon - the United States - to meet a new dawn, to redistribute the power and resources and to destroy the industrial potential of its main competitor - China. "One of the main objectives of the group that launched its activities more than a decade ago is to place all the responsibility precisely on China... - the responsibility for a major biological disaster allegedly caused by China intentionally as part of a biological war" (Kurginyan 2020f).

In his next address to the Internet audience, Kurginyan again raised the issue of censorship in respect of information about the artificial nature of SARS-CoV-2 and advanced some arguments towards the idea of its laboratory origin on the basis of his analysis of another selection of materials from foreign media. Kurginyan admits that possibly the research was originally carried out for the noble purpose of creating a new vaccine, but soon it could have caught the attention of bio-weapons developers. Kurginyan notes that when the situation with coronavirus got out of the specialists' control, the US censors were involved, and all information about the victims was deliberately hidden. Dwelling on the perlustration of COVID-19 information in Russia, Kurginyan admitted that the main centre controlling the public release of information about the origin of SARS-CoV-2 is located outside Russia - at the place where the experiments on "chimerical coronavirus" were 
initiated. The political scientist ended his lecture, in which he combined the problems of current geopolitics and epidemiology, this way:

Here is the picture I can present so far. Having analysed a huge number of events and having found those that are obviously connected into a coherent whole, I do not assert anything. I am just saying that if the meaning of the game exists it is on the territory I have just outlined (Kurginyan 2020g).

On May 29, Kurginyan undertook to analyse not only the social and political but also the anthropological consequences of COVID-19. Like Agamben and Žižek, he raised the questions concerning social isolation, quarantine, and other measures used to counter the infection. What will happen to people in a world where the pandemic has already turned many of the foundations of our existence upside down? Who will benefit from it? Who will lose? Who and how will be destined to preserve his/her/their humanity?

My conclusion is that what is going on around the coronavirus is addressed to man as such... $\mathrm{He}$, man, will either be finished off, finally turned into nothing, devoid of soul and spirit - or will bestir himself and seek the opportunity to acquire what was taken away from him, his very essence. He will not live in half-sleep. He will either be driven into this hell to the end... or he will have to... painfully break free of it... The scale of the systemic disaster called coronavirus is too great (Kurginyan 2020h).

A wide-ranging discussion about the coronavirus in relation to the political and financial games unfolding in the United States - the liberal opposition's revolt against Trump, enrichment of billionaires like Bill Gates, tirades against China, creation of mega-consortia like CEPI aimed to develop vaccines against the impending epidemics and make fabulous money on it - all this was presented by Kurginyan in his discourse on June 5 (Kurginyan 2020i). As a follow-up of this conversation, on June 18, the political scientist dwelled on the role of particular Western foundations and universities in inflating the scale of the coronavirus crisis ("Where there is power, there is colossal financing at times of crises; whereas where there is no power, there is bankruptcy and buying up of those who are not involved in power by those who are involved" [Kurginyan 2020j]). Further, on June 25, he analysed the role of American and other Western creators of the global pandemic crisis, as well as their plans to save humankind through universal quarantine, wearing masks, social distancing, permanent testing for the virus, and vaccination. Particular attention was paid to the "think-tank" - former US Secretary of Defence Donald Rumsfeld "engaged in universal quarantinisation that was impossible and would have seemed impossible to mankind before Rumsfeld did it... This quarantine was to be implemented in response to the use of biological weapons by the PRC against the United States" (Kurginyan 2020k).

In his speech on July 7, Kurginyan markedly changed the nature of his discourse on the pandemic, shifting from the global coronavirus situation to the Russian situation. This happened immediately after the nationwide vote on amendments to the Russian Constitution, which took place from June 25 to July 1. The political scientist wondered:

Should... the analysis of the big coronavirus game played on the global level be complemented by an equally detailed analysis of our domestic political situation? ...The deployment of coronavirus ecstasy on our territory at large and especially in the city of Moscow closely followed the scenarios written at the headquarters which runs the global coronavirus game... By analysing the big coronavirus game, we already understand what is happening in our homeland (Kurginyan 20201).

Gradually, the political scientist's reasoning reached a new level. For instance, in the text dated July 10, Kurginyan suggests that the COVID-19 pandemic should be treated as a global "transforming event" designed to dehumanise the whole of humanity. "Does COVID-19 reach the level of such a transformative event? Yes, it does" (Kurginyan 2020m). 
On July 23, the intellectual dwelled again on the role of global forces interested in supporting the coronavirus panic and related dehumanisation. According to his conclusions, the central figure in the process is the "tripersonal" Rumsfeld: a neo-conservative politician who united the former German Nazis and former Trotskyites in his party; a representative of the top military echelon; a businessman with a medical background, advocating the creation of an effective vaccine against the coronavirus (Kurginyan 2020n). On August 10, Kurginyan talked about the Big Pharma that uses the pandemic as a chance to create a new generation of "transformative" drugs to affect human biology. "What do these transformative drugs represent?" - the political scientist asked sarcastically. "It's not about nanochips in the human brain... It's much more real and much smarter" (Kurginyan 2020o).

On August 11, 2020, the world's first coronavirus vaccine was created in Russia, but Kurginyan preferred not to discuss this event in detail. Instead, on August 21, he gave a new lecture on the ways of transforming human biology, on the promotion of gene modification technologies, and on the pandemics as a contributing factor to their advancement (Kurginyan 2020p).

In the autumn of 2020, Russia proceeded to vaccination of its population, albeit yet on a very modest scale. Considering this practice in the context of general administrative and political measures against the pandemic, Kurginyan, on October 12, analysed the actions of the Russian authorities. He based some of his reasoning on historical analogies, recalling, for instance, the cholera riots in Russia at the time of Alexander Pushkin, caused by antiepidemic measures and their excess. Are we going to face COVID riots? According to Kurginyan, this may well happen owing to the specifics of the present Russian administrative machine which "copies the worst features of the Western system" (Kurginyan 2020q). On October 20, the political scientist discussed "the problem of effectiveness of vaccinating the population", emphasising that it is not a question of "indiscriminate denial of vaccination as such". Starting from that lecture, the focus of Kurginyan's attention was shifted towards the so-called vaccination ecstasy treated by the intellectual as a political technology that deprives the opponents of the right to have their opinion heard and turns them into "savages" (Kurginyan 2020r).

On January 5, 2021, Kurginyan noted that Russia was heading to a "stonewall", while experiencing the current coronavirus crisis. The Russian intelligence agencies, deprived of their political and ideological centre represented earlier by the CPSU, after the collapse of the USSR, now resembled Kshatriya left without the guidance of Brahmana, or a "collective Eustace" without a "collective Alex". According to the political scientist, there is still no clarity about the nature of the coronavirus. Perhaps, this is because of the ban on uninhibited research work? "The whole of the world health system is working... great microbiologists, virologists... Did you understand anything? $<\ldots>$ Do you understand the nature of the disease? $<\ldots>$ Where can you find the truth? Just explain to me, all of you - the Russian government, the Russian elite, the world community. Where does the slingshot come from?" (Kurginyan 2021a). On January 26, continuing the theme of the ban on free dissemination of information about the coronavirus, Kurginyan cited examples of punitive psychiatric measures against some Western virologists who spoke out about the artificial origin of SARS-CoV-2 and the possible ineffectiveness of vaccination against it. According to the intellectual, political debate is banned around the world, even in the West which has always prided itself on its freedoms. "The new secret inquisition will turn the whole world into a global Oswiecim, aka the realm of the Grand Inquisitor. And the coronavirus is only a tool in this Big Game" (Kurginyan 2021b).

On 3 February, Kurginyan, analysing the current situation, suggested discussing, along with the political aspect, the biological aspect of the pandemic problem: he spoke about complex biological constructs and on classical and modern concepts of immune resistance. According to Kurginyan, 


\begin{abstract}
Those who brought the subject of mass vaccination against the coronavirus on the world's agenda are guided by the scientific knowledge of the last century. The allegedly modern pharmacology - cumbersome, inflexible, focused on purely economic interest - relies on this flawed basis. It needs more and more vaccines that are produced within a long-outdated conceptual framework... Today, when the coronavirus vaccination is being persistently turned into a super ideology and, as declared, the only life-saving resort from the pandemic, people should specifically understand what vaccination is and how it works. When it saves and when it is destructive. The nature of antibodies, their varieties, the way they function in the human immune system. Otherwise, people find themselves in the position of savages (Kurginyan 2021c).
\end{abstract}

The modern knowledge about immunity should be made public, since otherwise, according to Kurginyan, people will blindly accept any decisions in the field of vaccination as the ultimate truth.

In the months that followed, Kurginyan repeatedly spoke out about the vaccination programme, pointing out, in particular, that it can be a blow to people's immunity, since even its staunch advocates do not have a full understanding of the biological antigen-antibody mechanism, and because there is no free public debate on this subject today. These statements received a wide response in Russia - both positive and negative.

It is not difficult to find that every lecture of the prominent political scientist is followed by active debate on the part of his admirers who share their impressions in the Internet space. Very many people perceive Kurginyan as the most honest thinker and a real guru whose lectures are a true revelation. However, one can find severe criticism of his statements, mainly in the media (Romanov 2021). Kurginyan, as a rule, does react to such attacks. He wittily and sarcastically denounces his critics, accusing them of scientific ignorance and political bias. The intellectual's relatively recent comments on Russia's vaccination programme remain sharply critical, while he connects the inevitable failure of the vaccination campaign with the pending political crisis which is so far yet avoidable (Kurginyan 2021d, 2021e).

\title{
Sources and materials
}

Agamben 2020a - Agamben, G. 2020a. L'invenzione di un'epidemia. Quodlibet. February 26. https:// www.quodlibet.it/giorgio-agamben-l-invenzione-di-un-epidemia

Agamben 2020b - Agamben, G. 2020b. Contagio. Quodlibet. March 11. https://www.quodlibet.it/ giorgio-agamben-contagio

Agamben 2020c - Agamben, G. 2020c. Chiarimenti. Quodlibet. March 17. https://www.quodlibet.it/ giorgio-agamben-chiarimenti

Agamben 2020d - Agamben, G. 2020d. Riflessioni sulla peste. Quodlibet. March 27. https://www. quodlibet.it/giorgio-agamben-riflessioni-sulla-peste

Agamben 2020e - Agamben, G. 2020e. Distanziamento sociale. Quodlibet. April 6. https://www.quodlibet.it/giorgio-agamben-distanziamento-sociale

Agamben 2020f - Agamben, G. 2020f. Una domanda. Quodlibet. April 13. https://www.quodlibet.it/ giorgio-agamben-una-domanda

Agamben 2020g - Agamben, G. 2020g. Fase 2. Quodlibet. April 20. https://www.quodlibet.it/giorgio-agamben-fase-2

Agamben 2020h - Agamben, G. 2020h. Nuove riflessioni. Quodlibet. April 22. https://www.quodlibet. it/giorgio-agamben-nuove-riflessioni

Agamben 2020i - Agamben, G. 2020i. Sul vero e sul falso. Quodlibet. April 28. https://www.quodlibet. it/giorgio-agamben-sul-vero-e-sul-falso

Agamben 2020j - Agamben, G. 2020j. La medicina come religione. Quodlibet. May 2. https://www. quodlibet.it/giorgio-agamben-la-medicina-come-religione

Agamben 2020k - Agamben, G. 2020k. Biosicurezza e politica. Quodlibet. May 11. https://www.quodlibet.it/giorgio-agamben-biosicurezza

Bossong 2020 - Bossong, N. 2020. Pandemiia - ne povod molchat' [The Pandemic Is Not a Reason to Stay Silent]. Decoder. April 21. https://www.dekoder.org/ru/article/pandemiya-ne-povod-molchat 
Country review 2020 - Stranovoi obzor: opyt Italii v bor'be s COVID-19 [Country Review: Italy's Experience in Combating COVID-19]. Prepared by the Department of International and Regional Cooperation of Accounts Chamber of the Russian Federation. April 21. https://ach.gov.ru/upload/pdf/Covid-Italy.pdf

Interfax 2020 - V Italii iz-za koronavirusa na polgoda vveli chrezvychainoe polozhenie [Italy Imposed State of Emergency for Six Months Because of Coronavirus]. Interfax. January 31. https://www. interfax.ru/world/693536

Kaspe 2020a - Kaspe, I. 2020a. Opasnost' i chistota. Pandemiia skvoz' prizmu (anti)utopii [Danger and Purity. The Pandemic through the Prism of (Anti)utopia]. IQ.HSE. June 30. https://iq.hse. $\mathrm{ru} /$ news/376188536.html

Kaspe 2020b - Kaspe, I. 2020b. Mesto dlya novoi Utopii: pandemiia koronavirusa cherez prizmu filosofii [The Place for a New Utopia: The Coronavirus Pandemic through the Prism of Philosophy]. RBC. Trends. July 15. https://trends.rbc.ru/trends/futurology/5f0dfb0c9a7947d5be2e3727

Kozenko 2020 - Kozenko, A. 2020. Radikal'nyi opyt Robinzona Kruzo. Chto dumaiut filosofy o pandemii koronavirusa [Robinson Crusoe's Radical Experience. Philosophers' Views about the Coronavirus Pandemic]. BBC News. Russian Service. April 12. https://www.bbc.com/russian/ features-52187015

Kurginyan 2020a - Koronavirus - mogil'shchik globalizatsii? Kurginyan rasskazal, v chem shans Rossii [Coronavirus - the Grave Digger of Globalisation? Kurginyan Tells what Russia's Chance Is]. Russia 24. March 31. https://www.youtube.com/watch?v=10r2vfU1Zyg

Kurginyan 2020b - Kurginyan otkrovenno o konspirologii vokrug COVID-19 [Kurginyan Talks Frankly about the Conspiracy around COVID-19.] Russia 24. April 21. https://www.youtube.com/ watch? $\mathrm{v}=\mathrm{cchlB} 3 \mathrm{I} 3 \mathrm{FxU}$

Kurginyan 2020c - Kuda vedet epidemiia COVID-19 i perezhivet li koronavirus rossiiskaia vlast'? [Where Is the COVID-19 Epidemic Heading and Will the Russian Power Survive the Coronavirus?]. April 26. https://www.youtube.com/watch?v=li-jyLJZpDU

Kurginyan 2020d - Kurginyan o koronaviruse: pochemu vrachi gibnut ot COVID 19, a Rossiia spit? Vstavai, strana ogromnaya! [Kurginyan about the Coronavirus: Why the Doctors Are Dying from COVID 19, while Russia Is Sleeping? Get up, the Vast Country!]. May 3. https://www.youtube. com/watch? $\mathrm{v}=\mathrm{LFjGTvY}-\mathrm{Cmo}$

Kurginyan 2020e - Koronavirus - ego tsel', avtory i khoziaeva. Kurginyan o koronaviruse 1: komu pomogaet Genprokuratura RF? [Coronavirus - Its Target, Authors and Hosts. Kurginyan about the Coronavirus 1: Who Is Helped by the RF General Procuracy?]. May 12. https://www.youtube. $\mathrm{com} /$ watch? $\mathrm{v}=6 \mathrm{gNHKctvJZo}$

Kurginyan 2020f - Koronavirus - ego tsel', avtory i khoziaeva. Kurginyan o koronaviruse 2: "Krasnyi rassvet" SShA $i$ ego zhertvy [Coronavirus - Its Target, Authors and Hosts. Kurginyan about the Coronavirus 2: United States' "Red Dawn” and Its Victims]. May 15. https://www.youtube.com/ watch? $\mathrm{v}=$ _w3I4grvYsk

Kurginyan $2020 \mathrm{~g}$ - Koronavirus - ego tsel', avtory i khoziaeva. Kurginyan o koronaviruse 3: "Kto eto sdelal, lordy?” [Coronavirus - Its Target, Authors and Hosts. Kurginyan about the Coronavirus 3: "Who Has Done It, Lords?"]. May 20. https://www.youtube.com/watch?v=ZYmcOcECYVM

Kurginyan 2020h - Koronavirus - ego tsel', avtory i khoziaeva. Kurginyan o koronaviruse 4: Kto otvetit za sotni tysiach smertei? [Coronavirus - Its Target, Authors and Hosts. Kurginyan about the Coronavirus 4: Who Is to Blame for Hundreds of Thousands of Deaths?]. May 29. https://www. youtube.com/watch?v=1Y20xdW7b1U

Kurginyan 2020i - Koronavirus - ego tsel', avtory i khoziaeva. Kurginyan o koronaviruse 5: Fort Detrik $i$ Bill Geits [Coronavirus - Its Target, Authors and Hosts. Kurginyan about the Coronavirus 5: Fort Detrick and Bill Gates]. June 5. https://www.youtube.com/watch?v=36NccB0eTpw

Kurginyan 2020j - Koronavirus - ego tsel', avtory i khoziaeva. Kurginyan o koronaviruse 6: Anderson, Fergyuson $i$ vsemirnaia isteriia [Coronavirus - Its Target, Authors and Hosts. Kurginyan about the Coronavirus 6: Anderson, Ferguson and the World Hysteria]. June 18. https://www.youtube.com/ watch? $\mathrm{v}=\mathrm{im} 3 \mathrm{~J} 4 \mathrm{fO} 55 \mathrm{TY}$

Kurginyan 2020k - Koronavirus - ego tsel', avtory i khoziaeva. Kurginyan o koronaviruse 7: Karantin kak transformatsiia obshchestva [Coronavirus - Its Target, Authors and Hosts. Kurginyan about the Coronavirus 7: Quarantine as a Transformation of the Society]. June 25. https://www. youtube.com/watch?v=01EC7f5Muhk

Kurginyan 20201 - Kurginyan o koronaviruse 8: Popravki v Konstitutsiiu RF i novaya kholodnaia voina Rossiya gotova? [Kurginyan about the Coronavirus 8: Amendments to the Russian Constitution and 
the New Cold War - Is Russia Ready for It?]. July 7. https://www.youtube.com/watch?v= $\operatorname{lnzWNDNPnqI} \& \mathrm{t}=61 \mathrm{~s}$

Kurginyan 2020m - Kurginyan o koronaviruse 9: Kovid i geopolitika: Putin i Tramp - chto obshchego $i$ kto pobedit? [Kurginyan about the Coronavirus 9: COVID and Geopolitics: Putin and Trump What Do They Have in Common and Who Will Win?]. July 10. https://www.youtube.com/ watch? $\mathrm{v}=\mathrm{dQZ0}$ _8ZF28o

Kurginyan 2020n - Kurginyan o koronaviruse 10: Trotskizm i neokonservatizm v SShA kak tvortsy nyneshnego krizisa [Kurginyan about the Coronavirus 10: Trotskyism and Neoconservatism in the USA as Creators of the Current Crisis]. July 23. https://www.youtube.com/ watch? $\mathrm{v}=5 \mathrm{~F} 8 \mathrm{OOOYOLC7} \mathrm{w}$

Kurginyan 2020o - Kurginyan o koronaviruse 11: Samoizoliatsiia i karantin spasaiut ili ubivaiut? [Kurginyan about the Coronavirus 11: Does the Self-Isolation and Quarantine Save or Kill?]. August 10. https://www.youtube.com/watch?v=Ijj2qsC2yas

Kurginyan 2020p - Kurginyan o koronaviruse 12: Kuda kovid vedet chelovechestvo i kto delaet GMO iz cheloveka [Kurginyan about the Coronavirus 12: Where the COVID Leads the Humanity and Who Is Making GMO out of Humans]. August 21. https://www.youtube.com/ watch? $=$ pKBlGJ0B7I8

Kurginyan 2020q - Kurginyan o koronaviruse 15: Chto by skazal Pushkin Sobyaninu i kogda zhdat' kovidnye bunty? [Kurginyan about the Coronavirus 15: What Would Pushkin Say to Sobyanin and When Are We to Expect COVID Riots?]. October 12. https://www.youtube.com/ watch? $\mathrm{v}=\mathrm{lz} 4 \mathrm{EwHN} 9 \mathrm{Sgk}$

Kurginyan 2020r - Kurginyan o koronaviruse 16: Massovaia vaktsinatsiia, ili Khotim li my v "Divnyi novyi mir" Khaksli [Kurginyan about the Coronavirus 16: Mass Vaccination, or Do We Want Huxley's "Brave New World"?]. October 20. https://www.youtube.com/watch?v=CiUB6Eybsn4

Kurginyan 2021a - Kurginyan o koronaviruse 18: Gde tvoi Tsentr, Yustas? Kto zakazal kovid $i$ preobrazovanie chelovechestva? [Kurginyan about the Coronavirus 18: Where Is Your Centre, Eustace? Who Ordered the COVID and the Transformation of Mankind?]. January 5. https:// www.youtube.com/watch? $\mathrm{v}=\mathrm{fQTH}$ cifla-o

Kurginyan 2021b - Kurginyan o koronaviruse 19: Kovid Vsemogushchii, ego ideologiya i ego karatel'naia psikhiatriia [Kurginyan about the Coronavirus 19: COVID Almighty, Its Ideology and Its Punitive Psychiatry]. January 24. https://www.youtube.com/watch?v=lakWlKKBaME

Kurginyan 2021c - Kurginyan o koronaviruse 20: Vaktsinatsiia pobedit kovid ili naoborot? Chto ne tak s vaktsinami i uchenymi? [Kurginyan about the Coronavirus 20: Will the Vaccination Beat COVID or vice versa? What Is Wrong with the Vaccines and Scientists?]. February 3. https://www. youtube.com/watch? $\mathrm{v}=\mathrm{fXtEisfUnxc}$

Kurginyan 2021d - Bezumie obiazatel'noi vaktsinatsii - eto put' k katastrofe. Vlast' Rossii roet sebe mogilu? [The Insanity of Compulsory Vaccination - a Path to Disaster. Is Russia's Power Digging Its Own Grave?]. July 31. https://www.youtube.com/watch?v=E1J_lrysSsA

Kurginyan 2021e - Epidemiya strakha i nedoveriia $v$ Rossii i progressiruiushchii rasseyannyi skleroz $v$ Kremle [The Epidemic of Fear and Mistrust in Russia and Kremlin's Progressive Multiple Sclerosis]. August 31. https://eot.su/tags/kurginyan-o-koronaviruse

Project (no details). - Proekt koronaFOM [CoronaFOM Project]. https://covid19.fom.ru

Romanov 2021 - Romanov, D. 2021. V svoem repertuare: Kurginyan nashel novuiu teoriiu zagovora. Kurginyan napugal YouTube ocherednoi portsiei konspirologii [Running True to Form: Kurginyan Discovered a New Conspiracy Theory. Kurginyan Scared YouTube with Another Conspiracy Theory]. Gazeta.Ru. July 1. https://www.gazeta.ru/comments/2021/07/01_a_13691090.shtml

Rudnev 2020 - Rudnev, R. 2020. Novye prava lichnosti: gosudarstvennye novatsii posle pandemii. Polemika s Agambenom [New Human Rights: State Innovations after the Pandemic. Polemic with Agamben]. Russian Legal Information Agency. April 20. http://rapsinews.ru/incident_ publication/20200420/305731864.html

TASS 2020 - Karantin na lainere Diamond Princess. Chto proiskhodit? [Quarantine on the Liner Diamond Princess. What's Going on?]. TASS. February 17. https://tass.ru/obschestvo/7779463

Wagner 2020 - Wagner, A. 2020. Granitsa zhivogo i mertvogo. Aleksandra Vagner - o filosofakh pandemii [The Borderline of the Living and the Dead. Alexandra Wagner on Pandemic Philosophers]. Radio Liberty. Blogs. October 27. https://www.svoboda.org/a/30913789.html

Zhaivoronok 2020 - Zhaivoronok, D. 2020. Tualetnaia bumaga kak simptom: pochemu tragediia COVID-19 prevrashchaetsia v filosofskii fars [Toilet Paper as a Symptom: Why the COVID-19 
Tragedy Turns into a Philosophical Farce]. Nozh [Knife]. May 4. https://knife.media/ philosophical-farce

Žižek 2020g - Žižek, S. 2020g. Clear Racist Element to Hysteria Over New Coronavirus. RT. Question More. February 3. https://www.rt.com/op-ed/479970-coronavirus-china-wuhan-hysteria-racist

Žižek 2020h - Žižek, S. 2020h. Nous sommes tous sur le même bateau, et son nom est Diamond Princess. L'Obs. February 14. https://www.nouvelobs.com/idees/20200214.OBS24860/nous-sommestous-sur-le-meme-bateau-et-son-nom-est-diamond-princess-par-slavoj-Žižek.html

Žižek 2020i - Žižek, S. 2020i. What the Coronavirus \& France Protests have in Common (and is it time for ORGIES yet?). RT. Question More. February 20. https://www.rt.com/op-ed/481213coronavirus-protests-slavoj-Žižek

Žižek 2020j - Žižek, S. 2020j. Coronavirus is "Kill Bill”-Esque Blow to Capitalism and Could Lead to Reinvention of Communism. RT. Question More. February 27. https://www.rt.com/ op-ed/481831-coronavirus-kill-bill-capitalism-communism

Žižek 2020k - Žižek, S. 2020k. Global Communism or the Jungle Law, Coronavirus Forces Us to Decide. RT. Question More. March 10. https://www.rt.com/op-ed/482780-coronavirus-communism-jungle-law-choice

Žižek 20201 - Žižek, S. 20201. What I Like about Coronavirus. The Spectator World. March 14. https:// spectatorworld.com/topic/like-about-coronavirus-slavoj-Žižek

Žižek 2020m - Žižek, S. 2020m. COVID-19 Lockdown Survival Guide: Guilty Pleasures, Valhalla Murders \& Pretending It's Just a Game. RT. Question More. March 28. https://www.rt.com/oped/484270-covid-Žižek-survival-guide

Žižek 2020n - Žižek, S. 2020n. Can COVID-19 Remind Us that SEX is an Important Channel for Sprituality? RT. Question More. April 20. https://www.rt.com/op-ed/486353-sex-covid19-spirituality-porn-Žižek

Žižek 2020o - Žižek, S., 2020o. May 1 in the Viral World is a Holiday for the NEW Working Class. RT. Question More. May 1. https://www.rt.com/op-ed/487517-slavoj-Žižek-new-working-class

Žižek 2020p - Žižek, S. 2020p. Epidemics are Like Wars, They Can Drag on for Years. RT. Question More. May 5. https://www.rt.com/op-ed/487713-slavoj-Žižek-epidemics-covid

Žižek 2020q - Žižek, S. 2020q. The Schmidt-Cuomo Digital Future is a highway to the Matrix. RT. Question More. May 14. https://www.rt.com/op-ed/488650-slavoj-Žižek-schmidt-cuomo-matrix

\section{References}

Agamben, G. 2011. Homo sacer: Chrezvychainoe polozhenie [Homo Sacer. State of Exception]. Moscow: Evropa.

Foucault, M. 2002. Politicheskaia funktsiia intellektuala [The Political Function of the Intellectual]. In Intellektualy $i$ vlast': izbrannye politicheskie stat'i, vystupleniia i interv'iu [Intellectuals and Power: Selected Political Articles, Speeches and Interviews], by M. Foucault, 201-209. Moscow: Praksis.

Nancy, J.-L. 2020. Virusnaia chrezvychainaia situatsiia [Viral Emergency Situation]. European Journal of Psychoanalysis. October 08. https://syg.ma/@journal-psychoanalysis/zhan-liuk-nansi-virusnaia-chriezvychaina-situatsia

Oslon, A.A. ed. 2021. Sotsiologiia pandemii. Proekt koronaFOM [Sociology of the Pandemic: Project CoronaFOM]. Moscow: Institut Fonda Obshchestvennoe Mnenie.

Žižek, S. 2020a. Pandemic!: COVID-19 Shakes the World. New York: OR Books.

Žižek, S. 2020b. Pandemic! 2: Chronicles of a Time Lost. New York: OR Books.

Žižek, S. 2020c. Monitor and Punish \& Yes, Please! The Philosophical Salon. March 16. https://thephilosophicalsalon.com/monitor-and-punish-yes-please

Žižek, S. 2020d. Dans l'ordre supérieur des choses, nous sommes une espèce qui ne compte pas. Philosophie Magazine. March 16. https://www.philomag.com/articles/slavoj-Žižek-dans-lordre-superieur-des-choses-nous-sommes-une-espece-qui-ne-compte-pas

Žižek, S. 2020e. Is Barbarism with a Human Face Our Fate? Critical Inquiry. March 18. https://critinq.wordpress.com/2020/03/18/is-barbarism-with-a-human-face-our-fate

Žižek, S. 2020f. Why are We Tired All the Time? The Philosophical Salon. April 2. https://thephilosophicalsalon.com/why-are-we-tired-all-the-time/\#_edn1 